\title{
THE STATE AND THE ECONOMY IN LATE IMPERIAL CHINA
}

\author{
ALBERT FEUERWERKER
}

The question, theoretical and empirical, of the relation of the state to the economy in preindustrial societies has of course not been ignored. Marx, for example, made this one of his central concerns in those sections of the Grundrisse der Kritik der politischen Ökonomie that discuss precapitalist economic formations. And nearly all research on China's economic and social history has, explicitly or implicitly, taken account of the imperial government - as a positive, or a negative, or a neutral factor in the development of the specific historical problem under study. What I propose to do in this brief paper is to consider a number of the ways in which the state in the Song, Ming, and Qing dynasties (i.e., from the eleventh through the nineteenth centuries, which we may call "late imperial China") did in fact interact with the economy; to discuss these policies and measures in the context of the potential means by which a premodern state may influence a premodern economy; and at times to compare the Chinese historical experience with that of early modern Europe from the fifteenth to the eighteenth centuries.

I am concerned with such questions as the extent to which Chinese administrators in the late imperial period deliberately intervened in the economy, how they did so, and with what results. What impact did their unwitting intervention (e.g., through the collection of taxes) have? Can the remarkable premodern economic growth that China experienced be attributed to the character or intensity of state intervention? How did the Chinese experience in these regards differ from that of early modern Europe, and to what degree does state intervention account for the more rapid growth of the European economy after 1750 ? So broad an essay as this one can, I fear, only demonstrate my own historical ignorance. But it may nevertheless be useful in identifying some particularly salient problems that merit further investigation. 
This large subject cannot be covered systematically in so brief a space. Before proceeding with my partial effort, let me indicate the broader range of distinctions that a more thorough presentation might require, and thus locate this paper more precisely. In the case of the "state," for example, we ought to distinguish at least between the court or dynasty on the one hand and the imperial bureaucracy on the other, as well as between central and local government. In considering the policies or actions of the state that can affect the economy, it is useful to distinguish those that require direct fiscal expenditures by the state (and thus control of some part of the output of the economy) from those that do not entail a direct expenditure of economic resources (although they call for other kinds of "expenditures," say of political power or prestige). The various measures undertaken by the government may primarily affect either the supply side of the economy (i.e., the structure and size of the production and distribution of commodities and services), or the demand side (i.e., the structure and size of the consumption of commodities and services). Their consequences may be measured, in other words, by changes in the values of a large variety of different indicators: for example, size of total output; size of output per capita; composition of output; relative importance of the sectors of the economy; levels of technology; price and wage levels; the ratio of consumption, savings, and investment; and the level of imports and exports.

Unfortunately, reliable and systematic statistical data for such measurements are rare in any premodern society, China included. We have certainly not yet compiled and analyzed all of the quantifiable information that can be derived from the public and private documents of premodern China. But even with the best of outcomes, I expect that for many critical measurements we shall always have to rely in some degree on indirect or partial evidence.

\section{Limited Direct Government Influence on the Economy}

State policies or actions with respect to the economy that required direct expenditures were limited by the amounts of money, goods and labor that the government controlled through direct and indirect taxation, corvee services, and other government income. Is it possible even to guess what proportion of national income in the Song, Ming, and Qing dynasties was controlled by the state and thus provided a potential means for influencing the economy directly? While there are abundant data about tax quotas and even some reporting of actual tax collections and receipts, the money value of corvée services prior to their gradual incorporation into the land tax in the late Ming and early Qing is probably impossible to estimate with any certainty. And estimates of national income (itself a concept with a variety of 
meanings in practice) can only be very rough. We shall need to begin with what I believe are a number of reasonable assumptions: (1) nonagricultural employment in China from the ninth century through the eighteenth was about 20 percent of total employment; (2) the value added per capita by nonagricultural labor (even in premodern handicraft industry) was greater than in farming, so that perhaps only 70 percent of national income originated in the agricultural sector; (3) 80 percent of cultivated acreage was planted in grain so that, assuming a constant return per acre, grain output was typically about 60 percent of national income $(0.8 \times 0.7=0.56)$; and (4) the output of grain per capita remained relatively constant at 500-600 catties $(250-300 \mathrm{~kg}$ ) of unhusked grain (paddy, $g u$ ). I have combined these assumptions with estimates of population size, normal grain prices, and typical annual government revenue to conjure into existence Table I.

I am very unsure of the Song figures especially: was it really the case, as they seem to imply, that the government in the Northern Song period had potentially greater ability to affect the economy directly than its successors? In a broad sense, such a conclusion would fit Robert $M$. Hartwell's hypothesis, based on a close study of the financial bureaucracy, that the notable economic expansion in the Northern Song was in part the result of policies adopted by experienced, technically competent fiscal officials with a national rather than a local outlook. ${ }^{2}$ These measures (for example, the encouragement of foreign trade, and an increased supply of money) tended to expand markets and to reduce the risk level of commerce. What this guess about the overall tax revenue as a proportion of national income does suggest, if we use five to seven percent as a typical figure, is that in this respect pre-twentieth century China was comparable to preindustrial Europe. Even in the mid-nineteenth century, public expenditure in most European states was still only 4-6 percent of national income. (In the twentieth century, of course, this proportion grew significantly to 20 percent and more.)

This comparison is somewhat misleading in that the public sector in Song, Ming, and Qing China was continuously able to levy general direct taxation, i.e., the land tax, while even at the end of the Middle Ages in Europe, direct taxes were still occasional imposts that were overshadowed in importance by indirect charges (customs duties, tolls, excises, etc.). When general direct taxation reappeared in Europe in the early modern period, it was the occasion for the convening of representative assemblies of property owners to give their consent to these levies. The dimensions of public income in Europe thus caught up with those of imperial China during the process of state-building in an age of absolute monarchy, in which both military costs and those of administration were shifted from the semi-public "feudal" 


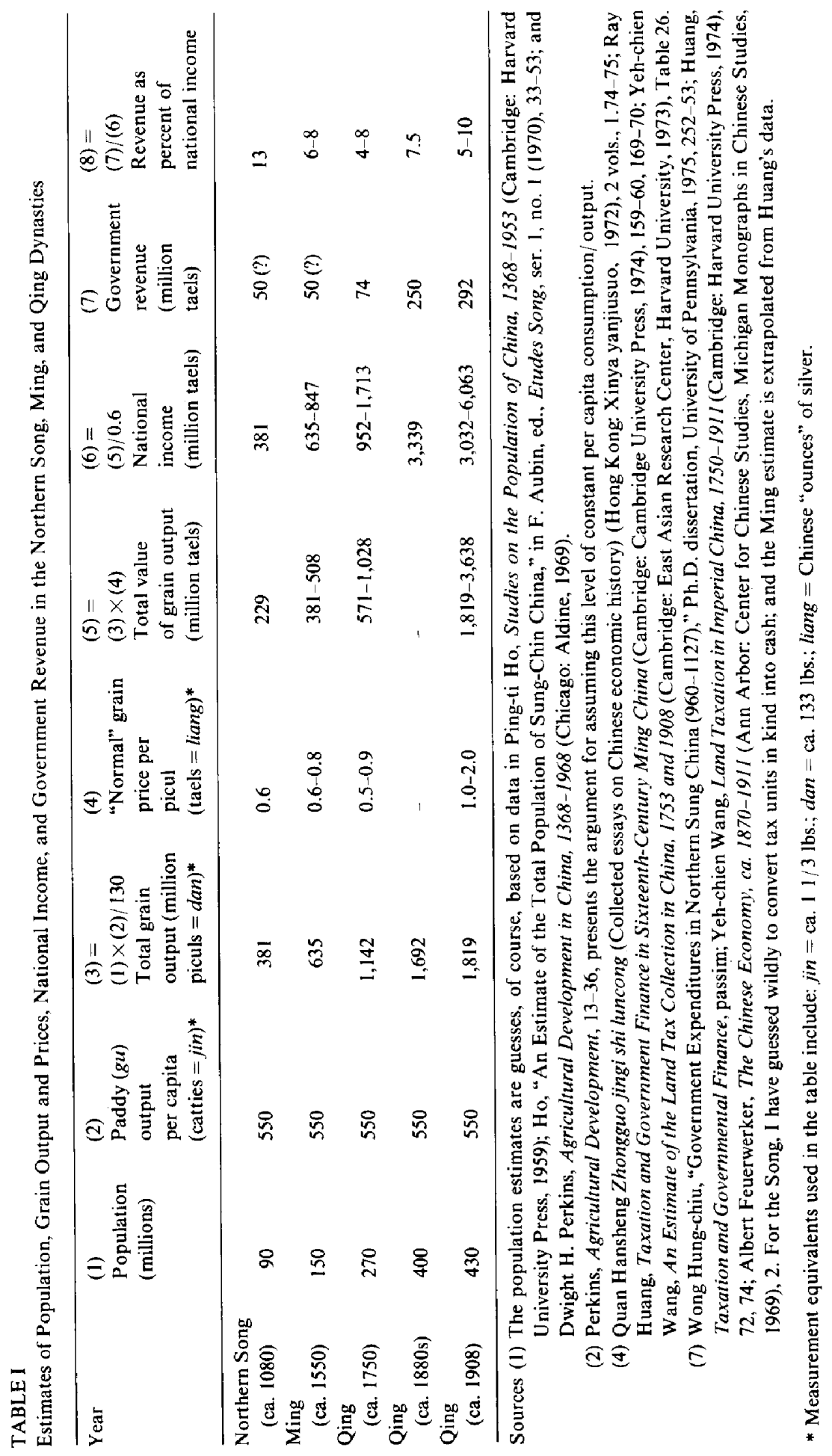


estates to the national level. But there does seem to have been a "natural" limit to the relative size of government consumption prior to the very recent past, which was shared by both China and Europe.

In part, this difference between the limited capacity of the state to affect the economy directly in the era of traditional or premodern economic growth and its enhanced capacity in the period of modern economic growth is a result of the absence even of the concept of sustained economic development per capita in the first case. To a remarkable degree, premodern societies have shared a primary concern with the question of how a relatively constant economic product should be distributed (usually in the interest of social order and the retention of power by the ruler). In circumstances where growth of output per capita was in fact uncommon, this restricted sense of what the state should undertake is understandable. It was reinforced by the real limitations that premodern technology (in transportation and communications, for example) set on the government's span of control, or what it could accomplish by administrative measures.

I wonder if that traditional span of control may not be in some way related to the degree of urbanization in premodern societies, that is, to the percentage of the population concentrated in substantial cities, where the state may exercise more direct control than it can wield over a population scattered in rural areas. In China, the city was the natural locus of the imperial bureaucrat, while in early modern Europe the cities, which had developed within a feudalized rural society at a time when the state practically did not exist, joined with the absolute monarchs to undo the rural lords. To be sure, there were possibly significant differences between China's pre-twentieth century cities and those of Europe prior to the industrial revolution (a matter that I cannot consider here). But is it too wild to speculate that Ming and Qing China were about as urbanized as early modern Europe; that China in the Song dynasty was perhaps even more so; and that the urbanization ratio and thus the direct economic leverage of the premodern state in both China and Europe were limited by similar constraints?

By 1600 , out of 75 million Europeans, 3.5 million or somewhat less than 5 percent of the total lived in perhaps one hundred sizeable cities. Twenty percent of the population were located in small rural towns, and more than 70 percent lived in the countryside. The seventeenth and eighteenth centuries saw the continued expansion of the urban population of Europe, and the nineteenth century of course was an era of intense urban growth. In 1800 , there were twenty-three cities with populations in excess of 100,000 , containing a total of 5.5 million persons or 3 percent of Europe's 192 million people. 
By 1900 , out of a total population of 432 million, 46 million or 10 percent lived in cities with more than 100,000 inhabitants.

Although his numbers are not strictly speaking comparable to the European estimates just cited, G. William Skinner's pioneering systematic effort to measure the extent of urbanization in the late Qing proposes that in 1893 there were 877 urban central places with 4,000 or more inhabitants whose combined population was 20.8 million or 5.3 percent of China's total. Alternative definitions of "urban" would increase the number of central places to 3,445 , and the urban population to 25.7 million or 6.5 percent of the total. Skinner concludes that 23.5 million persons, an urbanization rate of 6 percent, is a usable estimate for 1893 . His less reliable estimate for 1843 is 20.7 million urban residents and an urbanization rate of 5.1 percent. And he suggests, furthermore, that in both north China and Jiangnan, ${ }^{3}$ a higher percentage of the population lived in cities in the Song period than in the Qing, while the largest cities of the Tang and Song dynasties were of greater size than their Ming and Qing counterparts. ${ }^{4}$

The limits to urbanization - and, I am arguing, also to direct government intervention in the economy - in the preindustrial world were set by the availability of food supplies, the transport costs of bringing that food to cities, and by urban demographic patterns of probably higher mortality but lower fertility than in rural areas. Not everyone even in rural China was exclusively engaged in raising food. If we allow our earlier assumption of 20 percent of the total as the proportion of nonagricultural employment from the tenth century through the eighteenth, then at the least the agricultural labor force ( 80 percent of total employment) annually produced a surplus of 20 percent above what was required by minimum and customary consumption standards in order to maintain itself. Since, even with Engel's law, ${ }^{5}$ the wealthy among the nonagricultural population consumed more than the average amount of food, it is likely that the annual surplus was as high as 25 percent. This was the theoretical upper limit on the size of the nonagricultural population - including those who lived in cities. In the real world, however, total agricultural yield can easily fluctuate 25 percent or more from year to year due to natural (temperature, floods, droughts, insects, etc.) or man-made (war, political instability, foolish agricultural policies, etc.) disasters. Prior to the modern agricultural revolution, periodic subsistence crises were clearly inevitable, and set strict limits to the proportion of the population who could live and work in cities and towns, which had to be fed from the countryside.

With the severe limitations of premodern transportation I cannot deal here, 
except to note that in north China, at least, this was a factor limiting the number and size of cities until the advent of the railroad in the late nineteenth century. In circumstances of large annual harvest fluctuations, high transport costs, sometimes questionable reliability of the market as a secure source of supply (for example, due to popular opposition of shipments of food from grain surplus to grain deficit areas when prices were high), and inelastic demand (because income levels were generally low), the supply and maintenance of food stocks was an important constraint on the size and stability of urban places.

But food stocks are capital, indeed an important component (together with stocks of raw materials and of finished goods) of the total working capital of a preindustrial economy. And working capital prior to the industrial revolution represented a much larger proportion of total capital than the fixed capital invested in buildings, machinery, boats, carts, etc. The cost of creating and maintaining these food stocks (working capital) included warehousing, deterioration during storage, the implied interest paid if the stocks were built with borrowed funds, and the opportunity cost (of other investments foregone) if they were built with one's own means. The "ever-normal granaries" (changping cang) of imperial China, whose stocks in the eighteenth century were frequently built by the diversion of government tribute grains, may sometimes have been sufficient to cope with annual harvest shortfalls, but their total stocks were inadequate to smooth out large cyclical price fluctuations. One recent estimate of the adequacy of the combined stocks of the changping cang and the community granaries (she cang) of Sichuan in the early nineteenth century concludes that they held only'a twenty-three-day supply for the adult population. ${ }^{6}$ Frederick the Great of Prussia was able to maintain government stocks of grain equivalent to eighteen months' consumption scattered around the country; eighteenth-century France, in contrast, was unable to control wide and continuing fluctuations of grain prices in the last decades of ancien régime, and suffered widespread peasant revolts that prefigured the great risings of 1789 . In sum, maintaining the government granaries was expensive, and this too set a limit on the urbanization ratio.

W ang Anshi's "green shoots law" (qingmiao fa) was severely attacked by his opponents on the grounds that farmers had to pay exorbitant interest rates for these short-term loans from the government granaries. ${ }^{7}$ But the real costs (namely the market interest on the borrowed grain) were unavoidably high in circumstances of high market interest rates and capital shortages.

There was an additional large externality cost to maintaining substantial food stocks - in Europe at least. The matter of plague and typhus epidemics 
in urban areas spread by a large rodent population which fed on the stored food has not, so far as I am aware, been fully studied in the case of China.

The probability that epidemic disease was more destructive in urban conditions of crowding and poor sanitation than in rural areas is a major reason for believing that urban mortality rates were higher than rural ones. And the age-sex ratios of urban migrants (probably an excess of young, unmarried males) similarly suggests a lower overall urban fertility rate. It is thus possible that preindustrial cities in China and in Europe had a negative demographic balance even in normal times, and survived only through a continued flow of population from the countryside. This in itself set a limit to the degree of urbanization in premodern societies prior to some striking increase in the per capita productivity of agricultural labor. And so the effective span of state control or influence over the economy was also constrained. From a macroeconomic point of view, premodern economies, if not models of laissez faire or neo-classical economics' free movement of factors, were nevertheless only minimally accessible to control and direction by central government administrators.

\section{Varieties of Indirect Influence}

If the ability of the Chinese state to influence the economy directly through government revenues and expenditures was about the same from the Song through the Qing periods as that of early modern European states, it does not necessarily follow that their indirect capacities were the same. We need to look at the politics of the Chinese imperial government and how these indirectly affected the economy. If the concept of "feudal autocracy" (fengjian zhuanzhi), so current as an explanation in China today for that country's failure to develop its own "capitalism," is at all useful in understanding the problems of China's premodern economic history, it would seem to be in this connection that it should be considered. First, however, we should understand that the ways in which both direct and indirect measures were actually employed reflected the fact that from the Song onward, China's economy was essentially a market economy in which most of the economic results were determined by decisions made and actions taken in the private sector. Pockets of public ownership and activity remained in the economy and fluctuated in importance. But from the breakdown after the mid-eighth century of the Tang efforts to control the ownership of land - the primary means of production - by administrative measures and to subject marketing to strict regulation, there was a clear tendency for public and private to be more clearly differentiated and for the private sector to be enlarged at the expense of the public. 
The public land of the military agricultural colonies (tuntian) established in the early Ming was largely absorbed into the system of private land ownership by the sixteenth century, either through leases to civilian farmers or the transformation of military families into full-time farmers with permanent ownership rights in the land. Precisely the same process even more quickly undermined the Qing attempt to establish a Manchu type of landholding system in north China on lands mainly confiscated from the Ming imperial family and nobility. This banner land (qidi) was sold or leased to private Han Chinese farmers because it could produce a higher revenue in this manner than by being cultivated as "feudal" estates. The state's near monopoly of overseas shipping and trade at the beginning of the Ming gave way after the fifteenth century to a nominally illegal and largely private commerce with Southeast Asia and Japan. For strategic reasons, however, the Ming government's role in the horse trade with Manchuria and Mongolia remained significant. Even in the silk and porcelain industries, in which the Imperial Silkworks at Suzhou, Hangzhou, and Nanjing, and the Imperial Pottery at Jingdezhen figured so prominently, the great majority of the manufacturing establishments and trading firms were privately owned.

Cotton culture and manufacture, the most widespread handicraft industry in the Ming and Qing periods, was entirely a private enterprise. Cotton growing in Jiangnan and north China, spinning and weaving by peasant households, fulling, calendering and dyeing of the cloth in workshops located in market towns, the distribution of yarn and cloth by itinerant merchants, and its physical transportation by cart, boat, or human carrier - at each stage, the fixed and working capital were entirely private, and the relations between producers, merchants, and purchasers were established in the market. While the Shanxi banks (piaozhuang) ${ }^{8}$ that grew in importance in the eighteenth and nineteenth centuries developed ties with government departments and individual officials and handled some of their financial affairs, they were nevertheless basically privately financed and managed. And the old-style banks (qianzhuang) ${ }^{9}$ were even more clearly and completely in the private sector. Although they were subject to the regulation of salt officials, the salt workers and merchants, and their manufacturing and commercial properties, retained a private or semi-private status.

At times it appears that, rather than having burdened the private economy excessively with multitudinous taxes, the government's revenues were inadequate even for the critical expenses associated with its own maintenance against external military threats or internal popular uprisings. The Northern Song (960-1126), for example, in spite of the growth of its revenues, seems to have experienced difficulties in raising the expenses of wars against the Xixia 
and Jin; likewise for the Southern Song (1127-1279) in face of the Mongol military threat. By the mid-sixteenth century, the Ming faced unanticipated military costs largely because of the decay of the weisuo garrison system, ${ }^{10}$ which the founders of the dynasty had expected would be self-sustaining. Militia expenses to counter the incursions of the so-called "Japanese pirates" (wokou) ${ }^{11}$ in the south required at least two to three million taels (ounces of silver, the basic unit of account) annually in addition to seven to eight million taels for frontier defenses. The growing threat of the Manchus on the northern frontier, together with spreading peasant uprisings in the early decades of the seventeenth century, greatly strained the cumbersome and inflexible Ming tax system. Even with the land tax increases, which came in 1618 and after, the Ming financial problem was less one of an unbearable tax burden than that the tax structure and administration could not raise enough revenue to meet critical expenses and collected what it did with a good deal of inefficiency and inequity.

The land tax system copied by the Qing from the Ming with some modifications apparently produced adequate revenue in terms of the state's goals through the eighteenth century. But it was completely unable to respond quickly and sufficiently to the new demands for financial resources arising from the confrontation with the Western powers in the nineteenth century. In fact, the real burden of the Qing land tax declined steadily during the eighteenth century as the market price of rice rose while both the proportion of commuted payment in silver (the commutation rate) and the commutation price remained constant. Wang Yeh-chien has very ingeniously produced the best estimates that we now have of the size of the Qing land tax revenue in 1753 and 1908, and its share in total government revenue. In Table II, Wang's data are displayed together with calculations that I have made of the per capita burden of each tax item. These use a population estimate of 225 million for the mid-eighteenth century and 420 million for the beginning of the twentieth century, and conservatively assume a price rise of 100 percent between the two dates ( 150 percent might be closer to the truth). While prices increased in the eighteenth century, they declined in the second quarter of the nineteenth century (which probably has something to do with popular uprisings in mid-century), and only rose again in the last decades of the Qing dynasty. The estimates are rough, but they strongly suggest that the real burden of Qing taxes (which is the same thing as the real resources made available to the state) was at the mercy of unforeseeable price changes. Measured in real per capita terms, the total Qing tax burden was unchanged between 1753 and 1908; the land tax burden fell by half; the burden of the salt tax increased by perhaps 40 percent; and miscellaneous taxes became three times as heavy. 


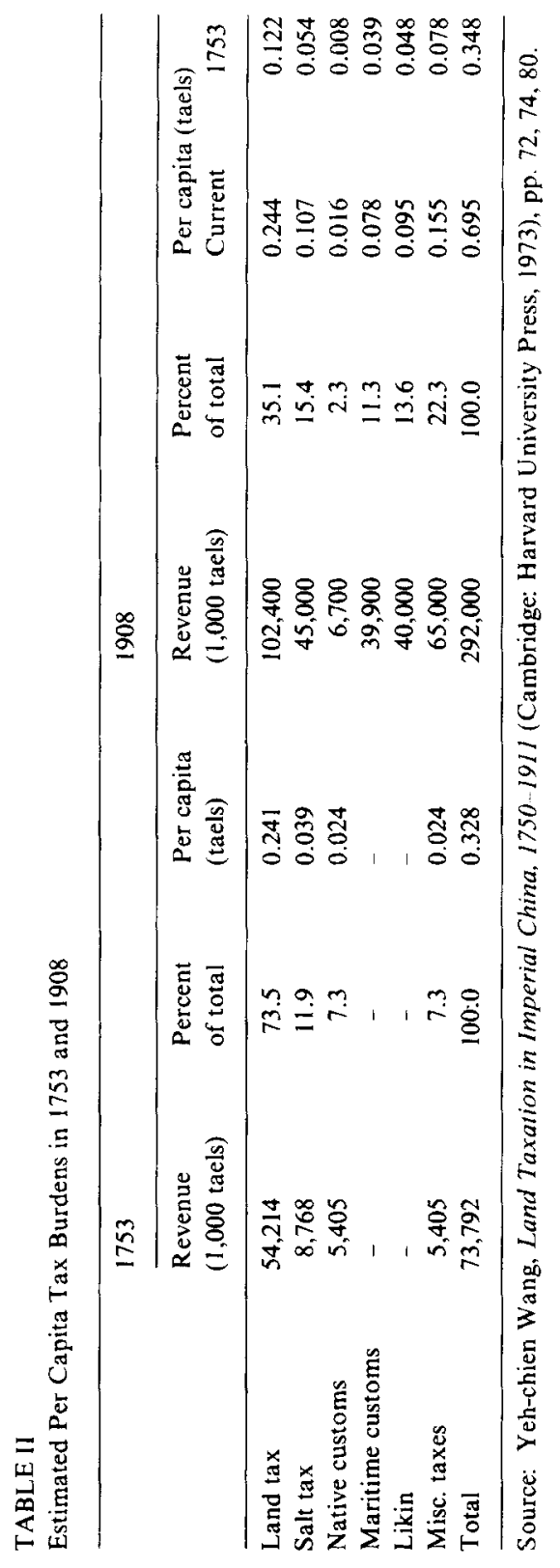


The consequences of a light fiscal hand, which in turn was partly due to an inflexible tax system, were thus not always desirable ones for the state or for the economy. But the pervasive support for light taxation in traditional China, which based itself on aspects of the dominant Neo-Confucian ideology, must itself not be taken lightly, especially as it was closely linked to the central social question of the incidence of taxation, and to the politics of the Chinese state.

The hierarchies of wealth, political power, and social status in China from the Song onward were dominated by elite lineages of which most of the constituent families were landlords of greater or lesser wealth. Many of the sons of these families aspired to success in the civil service examination system and thus by education shared the values of the much smaller number of their relatives and peers who did obtain higher degrees and go on to official careers in the imperial bureaucracy. We may thus schematically divide the dominant elite into (1) those who held office, had once held office, or expected to hold office (the bureaucratic elite); and (2) their much more numerous relatives and peers who might have a traditional education but lacked the formal qualifications - usually jinshi or juren degree status - for substantial office (the nonbureaucratic or local elite.) ${ }^{12}$ Although they came from similar social backgrounds, the bureaucratic elite and local elite (the latter are frequently called "gentry" by English-language writers) could and did differ in the degree to which they had a commitment to the state or government itself as opposed to sustaining gentry wealth, power and status in local society. This "ruling class," so to speak, shared the common necessity to control sufficient amounts of the surplus produced by the agricultural labor force to permit it as a group (although the fate of individual families might be more precarious) to continue to dominate. But the national outlook of the bureaucratic elite (what I have called elsewhere "Confucian raison d'état") could differ from the parochialism of the local gentry (what I have called "Confucian general will") with respect to such important matters as taxation and government economic policies. ${ }^{13}$

These contradictory tendencies were evident in the Song period in several different contexts. I have already noted Professor Hartwell's study of the Northern Song fiscal officials, the greater number of whom he finds to have come from high status lineages with a national orientation. By the twelfth century, however, the power of this group had been undermined by factionalism. Its successors were fiscal officials who, on the whole, were more limited in their outlook - i.e., more representative of the local gentry - and whose economic policies led to a contraction of the economic growth so apparent in the earlier Northern Song. Another Song example: Wang An- 
shi's "new policies,"14 although they did not derive from some populist ideology, in practice favored small landlords and independent owner-cultivators more than the owners of the larger estates (zhuangyuan), which grew up in the late Tang and Song. The reformers' efforts to cope with the serious problem of short-term agricultural finance, to commute corvée obligations into money payments (which were in part based on total wealth - i.e., landholdings - as well as the number of adult males per household), to stabilize supplies and prices by government purchases and sales, etc., clearly served to reduce economic risks in a largely market-oriented economy in the interest primarily of enhancing national strength. They were opposed by the "conservatives," led by Sima Guang(1019-1086), both because ideologically they seemed to represent an excessively "Legalist" approach to government and because they involved some costs to the wealthier landlords.

And as a third Song example of how the relative strength of bureaucratic as opposed to nonbureaucratic elite interests could indirectly affect the structure and development of the economy, compare, on the one hand, the growth of sizeable landed estates, which I have noted above and, on the other hand, the very clear tendency documented by Brian E. McKnight for privileged exemptions from the land tax and from "administrative labor service" (zhiyi) to be greatly reduced during the Song period. ${ }^{15}$ This process, McKnight points out, was reversed in the Yuan and Ming dynasties. The zhuangyuan were probably not so dominant as Sudo Yoshiyuki and the Tokyo University "school" of Song studies ${ }^{16}$ have suggested; they were not farmed as integral units, but rather rented out in quite small plots; and their tenants were not normally unfree laborers. They did, however, represent concentrations of local wealth, which were not appreciably reduced by Wang Anshi's fangtian junshui fa, ${ }^{17}$ or similar reform measures in the Southern Song. But the estates were apparently generally liable to taxation proportionate to their size, as their owners were subject to zhiyi. The situation is complicated by the warrantable suspicion that some wealthy households were able to manipulate this type of service for their own benefit. But overall, these three examples suggest how the relative political strength of sections of the elite with somewhat different primary orientations shaped the capacity and manner of indirect state influence upon what was already basically a market economy.

It was certainly consequential that the early Ming largely bequeathed the empty lands in north China resulting from the fierce wars at the end of the Yuan dynasty as estates to the politically privileged, relatives and supporters of the first emperor, Zhu Yuanzhang (r. 1368-1398). The early Qing, in contrast, opened up devastated Sichuan, the Han river highlands, and other 
areas that had been depopulated during the wars of the Ming-Qing transition almost entirely for resettlement by small peasant households. The state, in other words, could be important in defining property rights and thus shaping the economy. But at the same time, Zhu Yuanzhang was not happy with the elite property owners of Jiangnan, who had supported a rival claimant to power, and therefore confiscated many of the estates in that area and moved their proprietors to his new capital at Nanjing.

The Ming lijia obligations (services connected with tax collection), however, worked out so disastrously for the small farmers to whom the Jiangnan estates had been allocated (in fact as state tenants on government land, but de jure as owner-cultivators participating in the lijia rotation) that, by various subterfuges, the Song situation of large private estates farmed by tenants had been restored by the late fifteenth century. Lijia and other Ming service obligations were somewhat progressive in their incidence in that not only the number of adult males but also household wealth were considered in assigning families to the various tax categories. In practice, local landlords not holding examination degrees that would have exempted them from lijia and other corvee might sometimes be subject to very heavy burdens arising in part out of the cumbersomeness and inefficiency of the obsolescent Ming tax system, which had not changed with the changing economy. Many sought to evade taxes altogether by falsifying local records, bribing sub-officials, etc. There was thus an incentive for the elite as a whole - but especially for the bureaucratic elite - to exchange some part of their formal exemptions from service obligations in return for a more regularized tax system in which the burden would be more predictable and hence more suitable for the growing commercial character of the sixteenth-century economy. The "single whip" (yitiao bian) reform, ${ }^{18}$ a quite complicated process, which involved a good deal more than I have had space to point out here, came too late however. In any case, it had been pursued in the interest of elite commoners - the local gentry - and not of the tenants and landless laborers. And gentry privilege itself was severely shaken by the massive peasant uprisings of the seventeenth century, and then by the Manchu conquest.

What I have meant to point out again, in these Ming examples of changing property rights and tax burdens, was the existence of a range of indirect state influence on the economy along a spectrum that we can label Confucian raison d'état at one end (the interest of the state and its officials) and Confucian general will at the other (the interest of the local elite). Of course, in the middle ranges, the two blended into one another.

There seems also to have been a very rough alternation in the salience of these 
two orientations. If gentry interests pushed too far created the opportunity for the Manchu conquest, the early Qing dynasty combined the stick with the carrot to cope with gentry tax evasions. The 166I "Jiangnan Tax Case" cost thousands of wealthy gentry households accused of tax irregularities their examination degrees, ranks, posts, and property. But the Kangxi emperor ( $r$. 1661-1722) relented some - was it that he had imbibed more deeply than his predecessors in Confucian culture, including its "general will" tendencies? Imperial tax remissions in the period $1662-1711$ probably exceeded 100 million taels; fixing the ding ("commuted labor service") quota permanently at the level of the 1711 ding returns was certainly meant to exhibit the emperor's grace. But the Yongzheng emperor (r. 1723-1735) in turn was opposed to his father's leniency about local tax arrearages. Yongzheng acted to recover central government control of the land tax surcharges (in particular of the huohao or haoxian, "meltage fee"). On the one hand, he formally sanctioned these levies for the purpose of providing increased salaries (yanglian yin, "money to nourish integrity") to imperial officials; and on the other hand, he required that they be delivered to provincial treasuries for allocation, rather than being retained at the county level where they had provided personal income for the gentry and less scrupulous local officials. In implementing this policy, Yongzheng received his most important support from the Han bannerman Tian Wenjing (1662-1732), a strategically placed provincial official.

All of this suggests that, in addition to the interest of the state versus the excesses of the local gentry, we have an excellent example in this case of the distinct political interest of the emperor and dynasty as an additional element in the politics of indirect government influence on the economy. The emperor's role vis-à-vis the economy need not be, though it frequently was, limited to enjoying the resources made available to the court by the neiwufu (Imperial Household Office) and similar agencies in other dynasties. Note also that by incorporating the ding entirely into the land tax, Y ongzheng removed the last remaining formal gentry exemptions from tax obligations.

Of course it didn't last. Other surcharges escaped imperial control. The gentry, by employing the influence of their fellows in high office, successfully resisted all efforts to achieve accurate registration of their landholdings. And Yongzheng in 1727, probably for the first time in Chinese history, made tenant refusal to pay land rents a punishable crime.

I cannot here continue with the nineteenth-century situation where it might be argued again that the yangwu pai, and even more the reformers of $1898,{ }^{19}$ were advocates of economic policies and projects increasingly nationalistic in 
character and not always in the specific interest of the more conservative elements of the local gentry. The politics of the imperial state with respect to the economy, while they could never be such as would consciously undermine the society in which they operated, were at the same time not a simple monolithic absolutism that obstructed the growth of output. Indeed, it is evident that the combined direct and indirect influence of the state on the economy may not have been either large enough or of the right kind to promote "modern economic growth" in the changed world conditions of the nineteenth and twentieth centuries. But if the sustained growth of output per capita on the basis of continuous scientific and technical innovation (i.e., modern economic growth) was not achieved in imperial China, this was not primarily because the state always suppressed or relentlessly exploited protocapitalist elements. And the actions of the state certainly did not bar "premodern economic growth" - i.e., the expansion of total output and total population with no per capita increases, the production and distribution of more of the agricultural and handicraft products of essentially the same technology.

The failure to distinguish between the two partially discrete processes of modern and premodern economic growth may mislead us both with respect to the questions we ask about the relation of the state to the economy and with respect to the evidence we might seek in support of our answers. Premodern growth has occurred within a traditional technology that at best changed only very slowly and whose limits were at any time constantly being approached. The historical experience and institutional arrangements that might predispose to premodern growth may substantially impede later economic development of a different kind. And conversely, the scientific-technological and organizational inputs characteristic of the period of modern economic growth - and that is very recent indeed and limited so far to a minority of the earth's nations - were simply not present in the past. The administrators of the premodern state can hardly be faulted for their "feudal autocratic" failings in not applying them more vigorously.

Premodern growth was neither continuous, nor even, nor homogeneous in all the regions of China in the thousand years from the end of the Tang to the portentous confrontation in the nineteenth century with the Western powers, which themselves had begun the process of modern economic growth. The quantity and character of the actual inputs, direct and indirect, by the government to both the supply and demand sides of the economy were among the factors giving actual historical contours, according to time and place, to this premodern growth. At times the actions of the state certainly had a perceptible "lubricating" effect on the increase of population and total 
output in traditional China. But they could never be so decisive as the dynamics of the private economy itself.

\section{Government Influence on Agriculture and Commerce}

Direct state influence on agriculture, which accounted for perhaps 70 percent of the output value of the economy, was small as suggested by our estimate of taxes as a share of national income. And the share of government land of various kinds in the total cultivated area, although it varied by period and locality was never - even in the Yuan dynasty - very large. Even if we include the palace estates (huangzhuang) and aristocratic estates (zhuangtian) together with the military colonies, state pastures, etc., government property was limited in the early Ming and was even less at the end of the dynasty. In the eighteenth century, 92 percent of registered land was private land, and only 8 percent, including all the land nominally allocated to the Manchu banners (quasi-tribal military formations), was government land.

While there are many records of a government role in the opening of new land or the resettlement of territories depopulated as a result of war or civil war, for the most part this participation took the form of loans by local officials of seeds, tools, etc., to private farmers together with the remission of all or part of the taxes due on the newly developed land for a stated period of years. Rarely - unless we so consider the military colonies (tuntian) of the early Ming and Qing - was the colonization of new agricultural land undertaken under direct state auspices. But note that substantial amounts of land brought under cultivation in the provinces of Sichuan, Shaanxi, Hunan, Hubei, Guangxi, Yunnan, and Guizhou during the Qing were never included on the tax rolls - in effect, an important state subsidy for the settlement of these developing areas. In a similar manner, there are many indications of the contributions made by individual members of the bureaucratic or local elite to the introduction of new crops (maize, potatoes, cotton, for example), the spread of improved seeds and cultivation methods, and the very critical extension of double-cropping. But the augmentation of these inputs into agriculture did not result primarily from any government-led effort, and does not even seem to have been regularly coordinated by local or central officials.

Water conservancy projects, primarily for flood control but also for irrigation and transportation, in contrast, were matters in which government planning, administration, and funding were critical. In the Qing, the problem of the Huai river, for example, was a continuous and costly one, but some basic control of its flooding was essential to agricultural output. The large dikes and embankments where the Han river meets the Yangzi; the dikes 
along the Xiang river near Hankou; the effort to control the flow of the Chang Jiang (Yangzi river) above Yichang, where it passes through a low plain; the major flood-control systems in the vicinity of Lake Tai; and those on the Min river in north Sichuan, where it flows across the Chengdu plain these and similar projects were undertakings of such a scale and complexity that they could only have been carried out with substantial tax funds and some degree of centralized initiative and direction. Once completed, however, the administration of the allocation of water and the maintenance and repair of the dikes, dams, embankments, sluices, gates, etc., were left largely to the local gentry landlords and independent farmers whose agricultural properties benefitted from their operation.

And the critical importance of the Grand Canal, first for the economies of the Tang and Song dynasties, and then for their successors, hardly requires comment. It was of course primarily to facilitate the transport of tax grains and other goods to the northern capitals that the imperial governments undertook this enormous engineering project, which was beyond the capacity of the fragmented private sector to build. For nearly a thousand years, however, the tonnage of private shippers - and the most private of all, smugglers, too - probably outnumbered the official grain tribute, salt, and copper vessels on this major north-south commercial artery.

I have already mentioned the system of official granaries, which in various guises goes back at least to the Song. In its concern with maintaining a normal food supply, it reflected both the self-image and the self-interest of the Confucian ruler. The grain harvest was as important in the calculations of the French monarchs in the eighteenth century, and in the lives of the population for whom grain was the staple diet and principal item of expenditure, as it was to the Chinese rulers and people. But neither the elaborate state controls intended to prevent hoarding and speculation in times of poor harvests nor the alternating occasional efforts at free trade in grain as advocated by the Physiocrats were very successful in France. It seems that the basic problem for the French monarch was his inability to collect information about production and consumption, and to enforce his orders in the rural areas. If there was at least a superficial similarity between the obligations to popular welfare (and self preservation) that moved both the French king and the Chinese emperor, the Qing government, unlike the French, did not normally meddle with the rice trade. Apart from maintaining a system of granaries (scattered over the face of China with only small amounts in any one county, and in total amounting to no more than 3 to 4 percent of the annual harvest), it only occasionally commutated or diverted the tribute rice, and even less frequently allocated public funds for the 
purchase and shipment of grain to areas of local shortage. At least in the long era of domestic peace during the eighteenth century, these measures were generally sufficient to cope with food supply crises. Should we conclude that both the information - in the regular monthly reports on grain prices submitted by local officials - and the administrative efficiency of the Qing government were superior to France, or was the critical difference the effective operation of a large-scale private grain trade in China, which made most government involvement superfluous?

The commercialization of agriculture, that is, the sale of an increasing share of farm output on the market, does not necessarily result in greater personal freedom for the peasant farmer. In early modern Western Europe, the growth of market demand did by the eighteenth century result in tenants being largely freed of personal and labor obligations to now increasingly absentee owners, and their being able to make their own cultivating and marketing decisions in light of the likely prices for their inputs and outputs. In Eastern and Central Europe, however, the expanding demand for grain by the growing seaboard cities of Western Europe led to what has been called a "refeudalization" of the agrarian system after 1500. The lords of eastern Germany, the Hapsburg dominions, the Baltic provinces of Russia, and of Russia itself proceeded, forcefully when necessary, to deprive peasant and merchant of the limited freedoms that they had earlier gained, and to reimpose peasant labor services on the lord's land. The increased grain output was sold for export by the lords themselves. Probably the major reasons for these different outcomes in the two regions of Europe were the relative shortage of labor in the east (tying the peasant to the land was an effort to hold down labor costs), and the greater strength of the monarchy in the west, which thus could better resist, as in France, noble pressures for refeudalization.

Judging from the still insufficient studies that have been made, one might reasonably conclude that the status of the Chinese peasant - in the Qing period at least, and probably in most regions in much of the Ming dynasty as well - was closer to that of the French peasant of the eighteenth century than to the serf of eastern Europe. Some servile obligations remained in some regions (the most "backward," least "developed"), but the more degrading and burdensome had gone, if indeed they had ever been widespread: personal servitude, heavy and sometimes unlimited labor services, general insecurity of tenure, and the obligation to give children into service in the landlord's household. These were features of the kind of serfdom to be found in many parts of Central and Eastern Europe, but they were exceptional rather than common in late imperial China. 
This old order in Eastern Europe was transformed into the kind of society we frequently describe as capitalist or bourgeois, and that became the dominant type in nineteenth-century Europe. The emancipation of the serfs (except of course for the residual serfdom in France, which the Revolution brought to an end) was the work of the absolute monarchies. If the intellectual inspiration and justification came from the spread of the doctrine of reason of the Enlightenment, the immediate causes of these changes were the great wars of the eighteenth century. For either aggression or defense, the absolute monarchs required enlarged armed forces and the taxes to pay for them. Increased state revenue, in turn, was dependent upon higher agricultural output, a reduction of the "feudal" privileges of the nobility that obstructed higher productivity, and incentives to the peasant producers for their greater efforts.

I am not certain what the functional equivalent in late imperial China might have been for this "end of the old order in rural Europe," or what consequences would have followed for agricultural output and economic development. The general European changes, for which the positive model was the "agricultural revolution" in England (enclosures and continuous crop rotation in place of traditional open field practices, the development of an effective integration between farming and herding), were hardly relevant to the intensive rice and wheat cultivation of China. What changes, if any, in peasant status and agricultural practice that were both known and workable in the China of the Qing dynasty - not those that became possible only in the mid-twentieth century - could the Chinese state have executed? Perhaps none at all, maybe because the appropriate technology was unknown, the pressure of population on land was intense, and because the privileged landed elite provided the empire's key officials, whereas in Europe, the absolute monarchs were not beholden in the same manner to either baron or burgher. It is quite possible, in other words, that there was no way open for late imperial China to transform its economy on an indigenous basis. The Yongzheng emperor, however, who was never much liked by the Confucian gentry as his treatment by the traditional historians shows, issued decrees in 1727 and 1728 which transformed the status of the remnant of semi-free agricultural workers and other hereditary inferior social groups from that of jianmin ("base people") to liangmin ("ordinary commoners"). Did China need an enlightened despot?

Commerce in late imperial China, as already remarked, was primarily private commerce. The larger participants were in some manner usually licensed by officialdom (although this was certainly not so for the multitudinous petty traders). Yahang ("licensed brokers") were a common pheno- 
menon. They were frequently expected to help regulate the conduct of lesser firms in their lines of business. Commercial taxes were general, but not very heavy before the lijin ("likin") transit tax of the mid-nineteenth century. ${ }^{20}$ From the Song through the Qing, the trade in a number of different commodities was handled by state-controlled monopolies, but of these, only the salt monopoly was continuously important and of significant size. And 50 percent of the salt consumed in the mid-Qing was privately-sold, smuggled salt in any case. After the breakdown of the Tang regulated market system, domestic markets and fairs (which were apparently less common than in Europe, where fairs might be organized by monarchs, nobles, or the church) were developed mainly as the result of merchant initiatives. (There are exceptions, of course; Zhu Yuanzhang tried mightily to attract merchants to his capital at Nanjing.) In foreign trade, the state more frequently took an active part, by designating the cities on the coast and the inland frontier locations where trade was permitted; by participating directly in the trade itself, for example, in that part of it associated with the "tribute system" of the Ming and Qing dynasties; ${ }^{21}$ and by directing the duties and other revenues directly to the imperial court. Foreign trade might sometimes be prohibited or restricted for strategic or political-ideological reasons, but rarely successfully. When the Mongols were denied access to the Ming tribute system, they obtained what they needed of Chinese goods either by armed forays across the border or by smuggling. The Ming formal prohibition on Chinese ships trading abroad, which lasted from the first quarter of the fifteenth century until well into the sixteenth, did little in fact to hinder a growing private commerce with Japan and Southeast Asia.

In sum, it does not appear that traditional prejudices against commerce sometimes attributed to the Chinese state in fact hindered commercial development very much from the Song onward. But, do we know to what degree, if any, the total volume of trade grew faster than the growth of population and output? How much more intensely commercialized, as measured by per capita trade, was the Ming of the Wanli era (sixteenth century), or the Qing in the Qianlong emperor's reign (eighteenth century) than the Song of Wang Anshi's time (twelfth century)? Sometimes merchants could become very rich indeed, by plowing back their commercial profits into the market, as with the well-studied merchants of Huizhou or Yangzhou. But was there any difference between the quality and economic significance of the commercial activity of the Qing and that of the Song?

As with the expansion of the output of agriculture and handicrafts, the absolute growth in the scale of commerce from the tenth century to the eighteenth appears to have consisted mainly of more units of essentially the 
same activity. This was so in spite of the range of activities of some of the wealthy (salt, the rice and silk trades, pawnshops, mining, and shipping, at least for the famous Yangzhou merchants); and in spite of the quite complex organization of such businesses as silk weaving, the calendering of cotton cloth, shipping, and the proto-banking of the Shanxi merchants. Even the proliferation of huiguan (Landsmannschaften) ${ }^{22}$ in the Ming and Qing periods - indicative perhaps of an increased quantity of interregional commerce - also suggests that the actual presence of the principals was still required in order to close a deal, and therefore that institutionalized means for impersonal regularized conduct of long-distance trade (by correspondence, for example) were underdeveloped.

We have no long-term data on the movement of interest rates from which to judge the degree to which capital might have been in short supply during these many centuries. The economy was certainly not at the subsistence level, and premodern capital requirements are generally not large; individual examples of considerable accumulations are many; and there were some institutions (although they were weakly developed and not protected by formal legal codes and rapid access to judicial procedures) for pooling capital on a larger scale, e.g., partnerships, lineage common properties (yizhuang and the like), or joint ventures in the maritime trade with Southeast Asia. To a considerable degree, however, this capital was immobilized, tied up in things as they were, or even misused, misinvested, and dissipated. Analytically, the familiar purchase (voluntarily or not) of degrees, titles, and offices by wealthy merchants represented the conversion of commercial capital into government revenues to be used for day-to-day expenses. And the transfer of capital to landlords (by the purchase of rural properties; and also in marriage contracts?), while it redistributed income and drove up land prices, had no necessarily positive effect on agricultural production.

In seventeenth-and eighteenth-century Europe, in contrast, the state directly and indirectly played a part in expanding investment opportunities and reducing the risk with the consequence that capital previously tied up in traditional investments - as in China - was induced to participate in new ventures. To be sure, only in the nineteenth century was the European capital market capable of regularly channeling investments into industrial enterprises, but an important first step was to reduce the enormous overinvestment in land. Directly, the development of genuine funded national debts in the place of ad hoc loans made government bonds and annuities an alternative to land as a safe investment. Indirectly, government bonds were linked by the new modern public banks (the Bank of England was established in 1694) with the critically important process of creating "credit 
money." The spread of negotiable bills of exchange from the seventeenth century particularly facilitated the augmentation of the money supply through credit creation by the banks. The growth of a mortgage market was dependent on legislative and legal developments with respect to land titles and protection for the borrower so long as interest was paid. Similarly, the permanence of joint stock companies and the negotiability of their shares could only develop in a context of enabling commercial legislation and accumulated business case law. Neither Marxist-Leninist five-year plans nor Keynesian intervention to be sure, but the true history of the beginnings of modern economic growth in Western Europe is surely obscured if we do not give due weight to the political context and to the government-led institutional innovations that provided the "social space" and "social overhead capital" so critical for the transformation of the private agricultural and industrial sectors.

In late imperial China, we may schematically identify a section of the merchants who, like their counterparts in relatively stagnant places in early modern Europe, continued to invest their profits in honorific titles and land. In the leading commercial cities, there was a second group who, although more wealthy (like the leading salt merchants or the Shanxi bankers), aspired resolutely to obtain gentry status for themselves and perhaps even high office for their sons. There appear to have been few of a third category - the equivalent of the commission merchants, putting-out merchants, colonial traders, and industrial entrepreneurs of Western Europe who exploited the new investment opportunities of the seventeenth and eighteenth centuries with the aid of the increasingly efficient network of commercial institutions fostered in part by the state that was coming into being. I do not believe that the main difference in the relations between state and merchant in China and Europe is located in the often-cited exaction, by the Qing, for example, of millions of taels of "contributions" (baoxiao, etc.) from the salt merchants and the Guangzhou Cohong. ${ }^{23}$ Early modern European rulers also borrowed heavily from Italian and south German bankers to finance the establishment of the emerging absolute monarchies, to underwrite their wars and colonial ventures. Defaults and the refunding of these loans on terms unfavorable to the lender were frequent occurrences. But even if we take account of such practices in both China and Europe, the premodern state, as I have already suggested, was not in fact able to transfer directly any very large share of the national income from the private sector to the public.

Partly, there were not the same new investment opportunities in late imperial China - for example, on the scale of the cost-reducing potential of rural industry in England whose "new draperies" made it possible for the British 
woolens to dominate international markets; or those called forth by enlarged domestic demand arising from an agricultural revolution, which significantly increased the output per capita of agricultural workers; or, of course, those connected with the colonial trade. And, most important for the subject of this essay, the Chinese state had contributed little to the elaboration of the legal, financial, and commercial institutions that could facilitate the shift of commercial capital (i.e., circulating capital that was relatively easily withdrawn from poor investments) into industrial investment (i.e., fixed capital, "sunk" into plant, machinery, transportation) - while still protecting investors' liquidity through security markets and the like.

Premodern economic growth (as I have defined it above) is essentially a phenomenon of agricultural and commercial capital. In preindustrial England, it required eight times as much capital investment to employ a worker in agriculture as it did in (handicraft) industry. Modern economic growth, however, is the joint product of investment in fixed capital and in science and technology. It is not likely to develop out of the production of luxury handicrafts such as silk or porcelain. That Chinese government supervision or control of the Jingdezhen pottery industry, ${ }^{24}$ for example, apparently was a considerable burden on the private pottery firms is, it seems to me, of less consequence than the failure of the state - in spite of a long history of sophisticated monetary theory - to institutionalize the monetary basis for economic expansion.

A tremendous effort was expended by the Qing government to insure an adequate supply of copper for coinage by the imperial mints. The copper trade with Japan was encouraged and controlled; private investors were induced by advances of official funds to develop mines in Yunnan (in southwest China); the shipment of four thousand tons a year of refined copper some three thousand miles by boat, northward via the Yangzi river and Grand Canal, was a major undertaking, etc. But in fact, the supply of copper money was outside the effective control of the government (because of both counterfeiting and illegal melting of the coins, depending on the current market value of copper). And the government similarly lacked control over the supply of monetary silver(due to low domestic production, lack of control over bullion imports and exports, hoarding, etc.). Inflexibility of supply, lack of standardization, fluctuating silver/copper exchange rates - all of these increased the risks and uncertainty of business transactions. In fact, the notable expansion of commercial transactions accompanying the large economic growth of the eighteenth century was made possible in part by the issuance of a variety of paper notes and credit instruments, not by the state but by the private sector. None of this private paper money was fully 
institutionalized. To a large extent, the size and velocity of its circulation depended on private or personal factors; it had, of course, no legal standing nor the backing of a state-regulated central bank. How much credit money in fact was created is unknown; perhaps not really enough? Its supply could shrink as rapidly as it grew, if the implied silver (and copper) reserves would themselves diminish, as in fact they did in the second quarter of the nineteenth century as silver flowed out of China in payment for opium.

\section{Conclusions}

Non-development of a modern economy, the failure to begin modern economic growth, I am prepared to argue - but that would require another article - is "over-determined." It's not a particularly interesting theoretical question any more. Proponents of economic, political, cultural, social structural, demographic and other explanations have each adduced overwhelming arguments and evidence for their favored explanations. In fact, any one - or two - is a sufficiently mortal debility for the premodern economies and societies that they have studied. More is merely overkill. What we really don't know for sure yet is how modern economic growth begins - even in the case of Western Europe whose economic history has been minutely examined for more than a century. The common fate of most of mankind before the very recent past - slow and uncertain premodern growth of population and output where it occurred, stagnation or decline otherwise - has not (by historians at least) received attention comparable to the more fashionable problem of modern development, whether that be phrased as the Marxist "transition" from "feudalism" to "capitalism," the neo-classical growth model, or the perhaps now somewhat faded study of "modernization."

Late imperial China -from the tenth century to the nineteenth - experienced in world perspective a remarkable millennium of premodern economic growth (see table 1). Population and total grain output each increased by a factor of five or six over these centuries, in contrast to the first millennium of the imperial era - from the Qin (221-206 B.C.) through the Tang (618-906)during which, with often sharp fluctuations, a sort of plateau seems have been reached early and never overcome. (Europe's population growth was comparable - the estimates of course, like those for China, are sometimes more testimony to our faith than to our science. There were perhaps 39 million inhabitants in about 1000, 74 million before the demographically disastrous fourteenth century, a recovery to 50 million by 1450,105 million in about 1600,115 million about 1700 , and a total of possibly 190 million inhabitants in 1800.) While overall impressive, the growth of people and production in late imperial China was uneven in both rate and locale, and 
punctuated by severe fluctuations due to both natural and manmade disasters.

Neither the direct nor the indirect influences of the state on the economy were major factors determining the nature and rate of this premodern economic growth. That was largely decided by the dynamics of the dominant private sector of the economy. So far as they affected premodern growth the policies and actions of China's imperial government do not seem to have differed greatly in range or quality from those of the emerging national states of early modern Europe before, let us say, the seventeenth century. Certainly the acceleration of traditional growth in seventeenth- and especially eighteenthcentury China argues against the view that the late imperial "feudal autocracy" was a major obstacle to economic performance in the Ming and Qing periods. On balance, the actions of the state probably helped rather than hindered the long-term growth of population and total output. The state's control of or influence over only a very low percentage of gross national product at the very least limited negative interference with the private sector where the most remarkable Ming-Qing achievements originated.

Toward modern economic growth, on the other hand, the Chinese state contributed little if anything, in contrast to the history of early modern Europe. I have already suggested that this conclusion should not be surprising. It, rather than the still only partially understood European experience, represents the mode in world history. The fact that state policies and performance might have "lubricated" late imperial economic expansion does not imply any necessary forward linkages to the much different and much more difficult task of expanding not just total output but output per capita. The experience of the past is surely not irrelevant, but it may not all be positive for the goal of achieving economic growth in the modern epoch. Thus the Chinese experience of managing and participating in complex bureaucratic organizations may have left a positive legacy for the twentieth century. ${ }^{25}$ And similarly, the much higher degree of male literacy in Qing China than we have hitherto assumed, demonstrated in the admirable work of Evelyn S. Rawski, would presumably be conducive to the later achievement of modern economic growth. ${ }^{26}$ But the distancing - whether by cultural choice or due to political weakness - of the state from the private economy, while it may have facilitated premodern growth, could be a negative rather than a positive asset for a "backward" country seeking economic growth in the twentieth century, as Professor Gerschenkron has shown us. ${ }^{27}$

Does the contrast between late imperial China and early modern Europe derive, after all, mainly from the greater relative "success" of the Chinese 
experience under conditions of premodern economic growth? I refer of course to the achievement of a unified and integrated polity with an adequate customary standard of living for most of the population (in "normal" times), which was spared (or deprived of?) disquieting church-state conflicts and international wars (for the most part), where one found no "Sunday Confucians" and no domestic "modernist" challenge to a deeply rooted and genuine conservatism before the twentieth century. There was little reason for the Qing emperors and the bureaucratic elite who served them, while they still had the power to do so before the shameful nineteenth century, to follow the path of the Houses of Stuart, Bourbon, and Hapsburg and their bureaucratic administrators who built the modern European nation-states and purveyed some of the critical abstractions and institutions of law and property that unwittingly perhaps facilitated Europe's modern economic growth. The Chinese rulers already possessed "all under heaven" (tianxia), and they could hardly foresee how parochial that universal conceit would become.

\section{Bibliographic Note}

This is so general an essay, based largely on well-known secondary sources, that I have thought it unnecessary to burden the text with scholarly footnotes. The truth is, moreover, that to date neither the history of the Chinese economy nor the role of the imperial state with respect to the premodern economy have elicited scholarship comparable to the unmanageable riches that generations of European historians have given us. For a quick look at the state of contemporary Chinese and American scholarship see Albert Feuerwerker, ed., Chinese Social and Economic History from the Song to 1900, Michigan Monographs in Chinese Studies 45 (Ann Arbor: Center for Chinese Studies, 1982).

The following volumes are the best places to begin for English-language studies of China's economic history: Mark Elvin, The Pattern of the Chinese Past (Stanford: Stanford University Press, 1973), Dwight H. Perkins, ed., China's Modern Economy in Historical Perspective (Stanford: Stanford University Press, 1975), Dwight H. Perkins, Agricultural Development in China, 1368-1968(Chicago: Aldine, 1969), Yeh-chien Wang, Land Taxation in Imperial China, 1750-1911 (Cambridge: Harvard University Press, 1973), G. William Skinner, ed., The City in Late Imperial China (Stanford: Stanford University Press, 1977), Ping-ti Ho, Studies on the Population of China, 1368-1953 (Cambridge: Harvard University Press, 1959), Hilary J. Beattie, Land and Lineage in China: A Study of Tung-ch'eng County, Anhwei, in the Ming and Ch'ing Dynasties (Cambridge: Cambridge University Press, 1979), Ray Huang, Taxation and Governmental Finance in Sixteenth-Century 
Ming China (Cambridge: Cambridge University Press, 1974), Evelyn S. Rawski, Agricultural Change and the Peasant Economy of South China, (Cambridge: Harvard University Press, 1972), Shiba Yoshinobu, Commerce and Society in Sung China, trans. by Mark Elvin, Michigan Abstracts of Chinese and Japanese Works on Chinese History 2 (Ann Arbor: Center for Chinese Studies, 1970), W. E. Willmott, ed., Economic Organization in Chinese Society (Stanford: Stanford University Press, 1972), and Conference on Modern Chinese Economic History, August 26-29, 1977 (Taipei: Institute of Economics, Academia Sinica, n.d.).

The Chinese- and Japanese-language bibliography is large, often unsatisfying but with marvelous exceptions, and probably need not be cited for the nonspecialist reader. Current publications in the People's Republic of China may be followed in the annual Zhongguo lishixue nianjian [Yearbook of Chinese history] published in Beijing by the Chinese Historical Association, and in the quarterly Shixue qingbao [History information] issued under the same auspices. For Japanese works see the annual Books and Articles on Oriental Subjects Published in Japan edited in Tokyo by the Tōō Gakkai [Institute of Eastern Culture].

For my "quick-and-dirty" comparisons with the European experience, I have relied inter alios on Carlo M. Cipolla, ed., The Fontana Economic History of Europe, vols. 1-3 (Glasgow: Collins, 1972-1974), Harry A. Miskimin, The Economy of Later Renaissance Europe, 1460-1600 (Cambridge: Cambridge University Press, 1977), Jan de Vries, The Economy of Europe in an Age of Crisis, 1600-1750 (Cambridge: Cambridge University Press, 1976), Carlo M. Cipolla, Before the Industrial Revolution: European Society and Economy, 1000-1700 (New York: Norton, 1976), and Jerome Blum, The End of the Old Order in Rural Europe (Princeton: Princeton University Press, 1978). (I am aware that here, in the matter of the manorial reaction in Eastern Europe, as elsewhere in my article interpretations other than those that I have followed may now prevail, as for example in Alexander Gerschenkron, Continuity in History and Other Essays [Cambridge: Harvard University Press, 1968] and Richard Hellie, Enserfment and Military Change in Muscovy [Chicago: University of Chicago Press, 1971]. But this is a brief bibliographic note only.) See also John Hicks, $A$ Theory of Economic History (Oxford: Oxford University Press, 1969), and Philip Abrams and E. A. Wrigley, eds., Towns in Societies: Essays in Economic History and Historical Sociology (Cambridge: Cambridge University Press, 1978). 


\section{NOTES}

1. My use of "late imperial China" - i.e., the Song (960-1279), Yuan [or Mongol](1279-1368), Ming (1368-1644), and Qing [or Manchu] (1644-1911) dynasties - in contrast to the first millennium of empire (from 221 B. C.) derives from a view that critical political, economic, social, and intellectual changes in the eighth and ninth centuries sharply divide the latter epoch from the former. Among other things, post-Tang dynasty (618-906) China was essentially a market economy. Not all students of China's history accept this distinction.

2. Robert M. Hartwell, "Demographic, Political, and Social Transformations of China, 750-1550," Harvard Journal of Asiatic Studies 42.2 (December 1982): 365-442.

3. "Jiangnan," the relatively commercialized area south of the lower reaches of the Chang Jiang (Yangzi river).

4. G. William Skinner, ed., The City in Late Imperial China (Stanford: Stanford University Press, 1977), 21 1-249.

5. Ernst Engel (1821-1896), on the basis of many household budgets, generalized that the income elasticity of the demand for food is less than one.

6. Ts'ui-jung Liu and John C. H. Fei, "The Public Granary Institution of the Ch'ing Dynasty, 1644-1911," Yale University, Economic Growth Center Discussion Paper no. 299, October $1978,18$.

7. Wang Anshi( $1021-1086)$, Song dynasty reformer who as Chief Councilor sought to bolster the central government's finances by a series of sweeping measures including government loans to peasants at what were in fact low rates for the time.

8. The Shanxi banks, engaged primarily in inter-provincial fund transfers, had originated in the commercial needs of the ubiquitous merchants of Shanxi province.

9. The qianzhuang typically accepted deposits at interest, remitted funds, and financed moderate-sized local commercial transactions.

10. Weisuo, hereditary guard units established at strategic spots on the Inner Asian frontier and the seacoast, at the capital and along the Grand Canal.

11. Most of the "Japanese pirates" were in fact Chinese raiders from the coastal areas.

12. The civil service examination system, elaborated in the Song dynasty and later, provided most of the imperial bureaucrats. The highest degree, jinshi, was awarded at triennial examinations in the capital to no more than 200-300 successful candidates on each occasion. Juren was a provincial degree also awarded triennially. Lower degree holder (jiansheng, etc.) were not normally eligible for official appointments.

13. Albert Feuerwerker, State and Society in Eighteenth-Century China: The Ching Empire in its Glory, Michigan Monographs in Chinese Studies 27 (Ann Arbor: Center for Chinese Studies, 1976), $11-24$.

14. Wang Anshi's reform program may perhaps be seen as furthering central government interests at the expense of the local gentry, and hence was attacked as "Legalist," i.e., non-Confucian because it relied too heavily on laws and institutions rather than internalized Confucian morality.

15. Brian E. McKnight, "Song Legal Privileges," unpublished paper prepared for a Sino-American Symposium on Chinese Social and Economic History from the Song to 1900. Beijing, 26 October-l November 1980.

16. This is not the place to attempt to elucidate this complex subject, but the conflicting interpretations of the economy and society of the Song period offered by the historical schools of Kyoto and Tokyo universities have enormously influenced scholars elsewhere.

17. Fangtian junshui fa, new land surveys intended to eliminate old inequities and provide a basis for taxation based on the relative productive capacity of the soil.

18. The "single whip" reform, which occurred gradually over the years $1522-1619$, combined the various and numerous items of taxation under one or a small number of headings, and collected these taxes in silver. Moreover, much of the burden of corvee was in the process combined with the land tax.

19. Yangw u pai, the late nineteenth-century advocates of "self-strengthening" who borrowed military and industrial technology from the West for their pioneer enterprises. While most of the self-strengtheners did not venture so far as to advocate political changes, the "reformers of 1898 " envisaged the transformation of the empire into a constitutional monarchy on the model of Japan and Germany.

20. The lijin transit tax was first levied in 1853 in order to finance gentry-led militia units who fought against the Taiping rebels. It eventually became a major source of both provincial and central revenue and a considerable burden on domestic trade.

21. "Legal" foreign trade in much of the Ming and Qing periods was restricted to goods exchanged at the frontiers or in the capital in connection with "tribute missions" dispatched to China by her smaller continental neighbors and by the island states of the South Pacific ocean. In theory, the Chinese emperor was more concerned with this recognition of his superior status than with the potential profits of international trade. Practice early on had ruptured the tribute framework as Asian commerce expanded notably from the fifteenth century onward. But the theory and the ritual that embellished it were retained. 
22. The huiguan, organized in alien cities by merchants from a particular area, are sometimes referred to as gilds and indeed had that exclusive characteristic insofar as they operated to enhance and protect the interests of non-local merchants residing in cities outside of their home districts.

23. "Guangzhou Cohong," the licensed merchants at Canton (Guangzhou) who conducted the legal foreign trade with the Europeans at that port in the decades before the Opium War.

24. Jingdezhen in Jiangxi province for centuries was a leading pottery center. Both government and private kilns operated there, the private firms often as sub-contractors to the official kilns.

25. See Albert Feuerwerker, "Characteristics of the Chinese Economic Model Specific to the Chinese Environment," in Robert F. Dernberger, ed., China's Development Experience in Comparative Perspective (Cambridge: Harvard University Press, 1980), 261-305.

26. Evelyn S. Rawski, Education and Popular Literacy in Ch'ing China (Ann Arbor: University of Michigan Press, 1979).

27. Alexander Gerschenkron, Economic Backwardness in Historical Perspective (Cambridge: Harvard University Press, 1962). 